\title{
Rational Organizational Structure: For Brick- and-Mortar Lifestyle Retailers in India to Overcome Diseconomies of Scale and Protect Firm's Sustainability (ROLS-b)
}

\author{
H. R. Ganesha ${ }^{1}$ \& P. S. Aithal ${ }^{2}$ \\ ${ }^{1}$ Chief Executive Officer - Consulting Division, Gramss Retail Trading Private Limited, \\ Bengaluru - 560078, India and Post-Doctoral Research Fellow, College of Management \& \\ Commerce, Srinivas University, Mangalore - 575001, India. OrcidID: 0000-0002-5878-8844; \\ E-mail: hrganesha@yahoo.co.in \\ ${ }^{2}$ Vice Chancellor, Srinivas University, Mangalore - 575001, India. \\ OrcidID: 0000-0002-4691-8736; E-mail: psaithal@gmail.com
}

Area/Section: Business Management.

Type of the Paper: Research Paper.

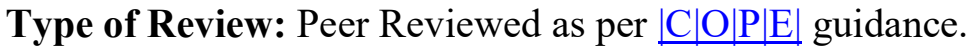

Indexed in: OpenAIRE.

DOI: http://doi.org/10.5281/zenodo.3988874.

Google Scholar Citation: IJMTS.

\section{How to Cite this Paper:}

Ganesha, H. R., \& Aithal, P. S. (2020). Rational Organizational Structure: For Brick-and-Mortar Lifestyle Retailers in India to Overcome Diseconomies of Scale and Protect Firm's Sustainability (ROLS-b). International Journal of Management, Technology, and Social Sciences (IJMTS), 5(2), 42-61. DOI: http://doi.org/10.5281/zenodo.3988874.

International Journal of Management, Technology, and Social Sciences (IJMTS) A Refereed International Journal of Srinivas University, India.

(C) With Authors.

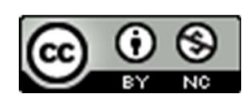

This work is licensed under a Creative Commons Attribution-Non-Commercial 4.0 International License subject to proper citation to the publication source of the work.

Disclaimer: The scholarly papers as reviewed and published by the Srinivas Publications (S.P.), India are the views and opinions of their respective authors and are not the views or opinions of the SP. The SP disclaims of any harm or loss caused due to the published content to any party. 


\title{
Rational Organizational Structure: For Brick-and-Mortar Lifestyle Retailers in India to Overcome Diseconomies of Scale and Protect Firm's Sustainability (ROLS-b)
}

\author{
H. R. Ganesha ${ }^{1} \&$ P. S. Aithal ${ }^{2}$ \\ ${ }^{1}$ Chief Executive Officer - Consulting Division, Gramss Retail Trading Private Limited, \\ Bengaluru - 560078, India and Post-Doctoral Research Fellow, College of Management \& \\ Commerce, Srinivas University, Mangalore - 575001, India. OrcidID: 0000-0002-5878-8844; \\ E-mail: hrganesha@yahoo.co.in \\ ${ }^{2}$ Vice Chancellor, Srinivas University, Mangalore - 575001, India. \\ OrcidID: 0000-0002-4691-8736; E-mail: psaithal@gmail.com
}

\begin{abstract}
A majority of organized brick-and-mortar lifestyle retailers in India believe that the brick-and-mortar retailing model ensures economies of scale as they keep opening new stores. Having more stores might help retailers to gain product sourcing advantages in addition to generating additional revenue to the firm but at the same time, it fails to provide any other benefits towards economies of scale as every new store comes with new one-time capital expenditures and recurring fixed expenses. Another misconception is that lifestyle retailing must follow an organizational structure (OS) that is adopted by their parent company and hence a majority of OS adopted by lifestyle retailers in India is dependent on organizational form. This study was not limited to just recommending a rational OS based on exploratory research and existing theories in the OS domain. Once the ROLS-b was designed, we have experimented with the proposed rational OS on one of the ten lifestyle retailers in the study to test the validity and reliability. Experimentation results empirically and qualitatively demonstrate that the existing belief of brick-and-mortar lifestyle retailers in India which assumes economies of scale and long-term firm's sustainability as the retailer increases the store count is just a misconception and does not hold. On the other hand, when we experimented the ROLS-b for over twelve months at over 25 percent stores of a select retailer, results demonstrate that these stores which have gone through the treatment have shown 5.34 times improvement in the store-level profit and 1.97 times in the firm-level profit in addition to eliminating a majority of gaps found in the existing OS that was leading to diseconomies of scale and deteriorating firm's performance.
\end{abstract}

Keywords: Indian Retail, Brick-and-Mortar Retail, Lifestyle Retail, Firm's Sustainability, Sustainable Business, Organizational Structure, Diseconomies of Scale, Organizational Form, Degree of Integration, Atmospheric Consequences, Bureaucratic Insularity, Incentive Limits, Communication Distortion, Bounded Rationality, ROLS-b.

\section{INTRODUCTION :}

Lifestyle Retailing in India: Owing to the sheer market size and potential, India has attracted many Global lifestyle brands who have successfully become lifestyle retailers too. Few Global retailers have attempted to offer their product assortment as being an SIS at select large MBO stores, few have offered their product assortment through having EBOs, few have shown their presence only in online stores and few have licensed their brands to third parties or entered into a Joint Venture to offer their products in Indian retail market. To name a few Decathlon, Lifestyle, Max, Levi's, Zara, United Colors of Benetton, Marks \& Spenser, H\&M, Mother Care, Carter's, Puma, Nike, Adidas, Reebok, Armani Exchange, Diesel, Gas, Gap, The Children's 
Place, Quiksilver, Superdry, Kappa, Bossini, Calvin Klein, Hanes, Tommy Hilfiger, Ed Hardy, Izod, Nautica, Arrow, U.S. Polo Assn, Jack \& Jones, Vero Moda, Tumi, Lee, Hero, Maverick, Wrangler, Fila, and Jockey. India also is a home for a vast number of lifestyle brands originated from India. One can list more than 5000 lifestyle brands in India [1], of which one could list only a few which can be tagged as wellknown/familiar/reputed Indian lifestyle brands cum retailers such as, Biba, Manyavar, Soch, Gini \& Jony, Blackberrys, Louis Phillipe, Peter England, Provogue, Monte Carlo, Mufti, W for Women, Oxemberg, Indian Terrain, Global Desi, Parx, S Kumar's, Vimal, Mini Klub, Aurelia, Sparx, Campus, Go Colors, Enamour, HiDesign, Lino Perros, Idee, Spykar, Killer Jeans, Flying Machine, Da Milano, Park Avenue, Ethnix, ColorPlus, Lux Cozy, WildCraft, 612 League, WLS, John Players, Fastrack, 109 F, Proline, Image, Jealous 21, Liberty, Paragon and few more. Few of these are successful in becoming organized lifestyle retailers catering to specific product categories and specific consumer groups. Few companies have been able to establish themselves as purely organized lifestyle retailers who cater to multi-category, multi-brand, multilocation, and multi-consumer groups and one can list all of them as there are only a few National level retailers such as a) Westside, b) Shoppers Stop, c) Central, d) FBB, e) First Cry, f) Toons, g) Wildcraft, h) Indian Terrain, i) Pantaloons, j) Brand Factory and few Regional level retailers such as, a) Kapsons, b) Ritu Wears Big Life, c) Stanmax, d) Bindals, e) Sohum Shoppe, f) City Life, g) Chunmun, h) Jade Blue, i) Neeru's, j) Mebaz, k) V-Mart, 1) The Chennai Silks, m) Saravana Stores, n) M\&M, o) Sirs \& Hers, p) Juelle, q) G3 Fashions, r) Pothy's, s) RMKV, t) Naidu Hall, u) Chandana Brothers, v) Nalli and w) Kalyan Silks. Dominantly a majority of lifestyle retailers in India offer just one of the groups such as a) product-specific; b) gender-specific; c) need-specific; d) fashion-specific; e) function-specific; f) category-specific; g) life stage-specific; h) occasion-specific, and very few cater to multiple products offering to multiple consumer groups. Each individual wants to have a unique identity that could be based on his/her, a) background such as nationality, ethnicity, culture, subculture, social class, affiliation, environment, etc; b) experiences and c) choices. Lifestyle brands attempt to evoke emotional connections between consumers and they need to have a unique identity and most importantly lifestyle brands are increasingly becoming one of the key components of consumer's self-expression [2].

To ensure the scope of this study is focussed, we define lifestyle retailers as the ones, who attempt to offer a complete solution for a specific or wider lifestyle needs of consumers through their products such as Apparel, Footwear, Accessories, and Lifestyle Essentials with an ultimate goal of their products being key contributors of an implicit or explicit statement of consumers personality and identity. Lifestyle retail market size in India is expected to reach 130 billion USD by the year 2023 which is a 77 percent growth when compared to the year 2013 [3]. Based on India's 2011 census, the United Nation's (UN) Department of Statistics and Program Implementation estimates the Indian population to reach close to 1.38 billion by the year 2020 [4]. It is estimated that more than 300 Global lifestyle brands have plans to open their stores in India this year [5]. Organized retailing in India is expected to have approximately 25 percent of the market share by the year 2021 which was at 12 percent in the year 2017 [6]. In addition to this humongous population, exponential growth in several working women, double-income families, middle-class consumer segment, increasing disposable income, rapid adoption of fashion, urbanization, the overall size of Indian retail industry, more and more unorganized retailers becoming organized, the emergence of modern retailing formats and most importantly, an enormous increase in internet penetration/usage, simply caution existing and upcoming lifestyle retailers in India to revisit their existing OS.

Organization Structure of Lifestyle Retailers in India: Unlike lifestyle retailers in the developed countries, market penetration of organized lifestyle retailers is still low in India. This could be one of the reasons for the absence of the adoption of a standard OS by the lifestyle retailers in India. A majority of OS of lifestyle retailers in India is driven by the principal/original business nature of the parent group such as a) Manufacturing-Centric Retailers (example: Relaxo Footwear); b) Brand-Centric Retailers (example: Toonz) ); c)Store-Centric Retailers (example: FBB); d) Investors-Centric Retailers (example: First Cry); e) Conglomerate-Centric Retailers (example: Westside); f) Global Expansion-Centric Retailers (H\&M); g) Family-Owned Retailers (example: Bib a); h) Product-Centric Retailers (example: Me \& Moms).Despite any 
empirical pieces of evidence, the belief is that the brick-and-mortar retailing model ensures economies of scale as the retailer increases the store count. Having more stores might help retailers to gain product sourcing advantages in addition to generating additional revenue to the firm but at the same time, it fails to provide any other benefits towards economies of scale as every new store comes with new one-time capital expenditures and recurring fixed expenses. It is fine to adopt an OS that is aligned with the basic principles and nature of the key investor. However, to ensure long term sustainability of a lifestyle retail firm in addition to conquering diseconomies of scale it is recommended to adopt a Consumer-Centric organization structure. In this exhaustive study, we intend to design a standard organization structure that is rational and consumercentric and appropriate in the Indian context.

\section{LITERATURE REVIEW :}

Diseconomies of Scale: The literature on diseconomies of scale can be traced back to the year 1937 when Coase described it as a result of three key attributes such as i) cost of determination or planning; ii) cost of resource misallocation; iii) cost of lack of motivation [7]. Later in the year 1975 Williamson for easier operationalization categorized diseconomies of scale into i) 'atmospheric consequences' that refer to as the size of the firm expands the tendency of increase in specialization increases which makes it hard for the employees to understand the key purpose of corporate activities; ii) 'bureaucratic insularity' that refer to as the size of the firm expands the accountability of senior management team reduces over results of lower ranks of the organization in addition to making senior management team insulated from reality and making them focus on maximizing their personal benefits rather than the overall firm's performance; iii) 'incentive limits of the employment relation' that refer to as the size of firm expands the incentive systems or employees tend to change towards tenure and position based rather than merit based incentives which puts larger firms at a disadvantage as compared to smaller firms; iv) 'communication distortion due to bounded rationality' that refer to as the firm expands the hierarchical layers in the organization also increase which makes it inevitable to communicate without distortion and significantly reduces the ability of senior management personnel to make decisions based on facts [8-9]. However, Williamson's first and second categories of diseconomies of scale broadly correspond to the cost of determination/planning, third to the cost of demotivation, and the fourth to the cost of resource misallocation conceptualized by Coase. Few studies whether or not explicitly specifying the term diseconomies of scale have identified factors that have negative consequences in addition to leading to diseconomies of scale thereby limiting the overall growth of a firm that corroborate with Williamson's theoretical conceptualization of diseconomies of scale such as i)rigidity to change [14], excessive rigidity [15], unexplained wage differential [16], insularity [17], R\&D cost control [18], alienation [19], low job satisfaction in large organizations [20], rigidity [21], insularity from reality [22], monitoring costs and inadequate effort levels [23], cost-consciousness [24], and low motivation levels [25]under the 'atmospheric consequences' category; ii) risk aversion [26], firm age leads to insularity [27], organizations larger than optimum [28], owner-manager conflict of motivation [29], increase in administration [30], poor understanding of changing market needs by the R\&D [24], perpetuation of organization form [31], and bureaucratic rigidity [32] under the 'bureaucratic insularity' category; iii) R\&D incentives [18], low productivity in $R \& D$ [33], employment contracts [34], quality of $R \& D$ employees [24], limits to entrepreneurship [35], weaker incentives in bureaucracies [32], and employment contract disincentives in $\mathrm{R} \& \mathrm{D}$ [36] under the 'incentive limits of employment relation' category; iv) specialization leading to poor communication [14], information loss [37], communication losses [38], R\&D coordination levels [18], information signal delays [39], lower efficiency levels [40], control-loss [41], and processing bottlenecks [13] under the 'communication distortion due to bounded rationality' category. While these four categories of diseconomy of scale affect the expansion, performance and long term sustainability of a particular firm two important factors could offset the diseconomies of scale and are central to transaction cost economics such as i) 'organization form' that refer to adopting organization forms appropriate for the business; ii) 'degree of integration' that is determined by three key factors such as a) uncertainty; b) frequency of transactions; c) asset specificity of which asset specificity is an important driver of the integration [8-14]. Both these 
moderators are core to this study in addition to becoming basic pillars of the rational organization structure (ROSE-b) we are intending to design to help organized brick-and-mortar lifestyle retailers in India to overcome diseconomies of scale and protect their long term sustainability.

Organizational Structures: A majority of lifestyle retailers in India have adopted organization structures that are determined by their organizational form. OS can be defined as the design/framework that specifies as to how overall organizational aims/goals are achieved through a) allocation of tasks to each employee, b) coordination methods among employees, and c) supervision/hierarchical levels. One can find many different types of OSs in the literature such as i) 'simple structure' that refer to direct, informal and low-complex structures; ii) 'functional structure' that refers to classifying activities based on logical similarities; iii) 'multidivisional structure' that refer to creating divisions within a firm responsible for general administration of different functions; iv) 'matrix structure' that is composed of functional and multidivisional structures; v) 'hybrid structure' wherein different OSs are adopted based on their relevance and need for adoption together by a firm; vi) 'network structure' adopted by firms that are involved in products and services with short life cycles, faced with rapid changes in the technology and servicing dispersed/specialized markets; vi) 'bureaucratic structure' that rely on standard operating procedures, governance methods and mostly adopted by large conglomerates; vii) 'team-based structure' in which a majority of decisions are decentralized; viii) 'virtual structure' that is mostly centralized in terms of structure and rarely has specialized divisions; ix) 'no boundary structures' wherein the usual commanding hierarchy is eliminated. It is not just about the type of OS, what is also important is the structural model that is based on six key hypotheses such as i) the firms exist to achieve certain predetermined goals; ii) structural form is based on a specific set of conditions; iii) a firm is effective when the environment confusion and individual priorities/differences are restricted by reasoning norms; iv) specialization might enable high-level of individual performance; v) structured coordination and predefined control systems are necessary to achieve effectiveness; vi) firms' s inefficiencies are found and can be solved by restructuring or development of new systems. It is also inevitable to understand the factors that determine an OS such as i) firms short-term and long-term strategy; ii) physical capacity of an organization; iii) existing employees in an organization; iv) organization's input and output scope; v) financial and materialistic resources of an organization [42-45].

Firm's Sustainability: 'Sustainability' as an area of research has attracted a large number of researchers wherein a majority of the studies have focussed on sustainability concerning the environment and very few have focussed on the firm's sustainability. Despite various researchers defining a firm's sustainability from different perspectives, we found Wirtenberg, Harmon, Russell, and Fairfield's definition suitable for our study. They define a firm's sustainability as a 'company's ability to achieve its business goals and increase long-term shareholder value by integrating economic, environmental, and social opportunities into its business strategies' [46]. We believe that the term 'company's ability' in this definition though looks simple has a larger meaning that indicates firm's capability in adapting rational Marketing Mix that is driven by a well-defined OS and optimized degree of integration that is inevitable to achieve firm's long-term sustainability that encompasses economical, environmental and social interests. In addition to achieving a rational mix of " $4 \mathrm{P}$ 's" such as product, price, promotion, and place what determines the long term sustainability of a lifestyle retailing firm is how their OS is designed that ensures i) equal and high weightage to overall store performance-related key result areas (KRAs) and key performance indicators (KPIs) for all the employees in the organization irrespective of the department/function they represent; ii) systematic empowerment of store employees; iii) systematic decentralization of control systems [47].Past studies have indicated a few key factors that influence the overall firm's sustainability and success such as a) the role of human resource development [48]; b) creativity and innovations [49]; c) situational leadership style [50]; d) organizational capabilities [51]; e) stakeholder influences [52]; f) business practices [53]; g) ability to face changing market environments [54]; h) effective conversations-for-action [55]; i) strategic change [56]; j) management capabilities to efficiently use resources (physical, human and financial) [57]; k) architypes of organization [58]; 1) leadership effectiveness [59]; m) rightsizing of human resources [60]; n) leadership styles [61]; o) competitive dynamics and strategic consistency [62]; p) humanistic and ethical approaches 
beyond economic criteria [63]; q) employee attitudes [64]; r) relationships between the people inside and outside the organisation [65]; s) perspectives of people in the bottom of the hierarchy on people above them in the hierarchy [66]; t) switch leadership [67]; u) strategic planning [68]; v) reputation building [69]; w) control-self assessment [70]; $x$ ) organizational culture [71]; y) market-orientation [72]; z) training [73-74]; aa) sales personnel empowerment [75-76]; ab) sales pitch [77]; ac) performance measures whether or not inputs-driven [78-79]; ad) consumer communication tactics [80]; ae) consumer orientation [81]; af) store image [82-84].

In a nutshell, a majority of past studies corroborate with our hypothesis that the OS plays an important role in conquering diseconomies of scale and protecting a firm's long-term economical sustainability that would also indirectly improve environmental and social interests of a firm.

\section{PURPOSE AND OBJECTIVES OF THE STUDY :}

The prevailing assumption is that a majority of lifestyle retailers in India are bewildered with various theories, perspectives, models, frameworks, and strategies available in the OS domain and hence, they are not able to design an appropriate OS that can conquer diseconomies of scale and protect firm's sustainability. There is a wide gap in the understanding of interlinkage between theories, perspectives, models, and frameworks available in the domain that is globally accepted as one of the most efficient organizational designs. This gap can be reduced if we can demonstrate the correlation among various theories, perspectives, models, and frameworks available in the existing literature with the empirical pieces of evidence from India in this study and transpire the research outcomes into a rational OS design which would then be useful for organized brickand-mortar lifestyle retailers in India to design appropriate strategies concerning organizational design. The need for this research indeed was originated due to various gaps found in theoretical, descriptive, empirical literature available in the OS domain such as i) a majority of studies have focussed on diseconomies of scale concept in a manufacturing context and not service context; ii) a majority of studies have focussed on firm's sustainability in the environmental context and not enough studies focussed on economical contexts; iii) absence of an integrated OS design for lifestyle retailers in the Indian context; iv) a majority of lifestyle retailers in India follow and practice OS incorporated by consumer goods, hospitality and restaurant brands and retailers, and, most importantly; v) lifestyle retailers in India are unable to overcome diseconomies of scale and protect firm's long-term sustainability. The present study proposes to a) understand lifestyle retailing market in India; b) understand evolution and performance of Indian lifestyle retailers; c) understand the existing OS of a few select lifestyle retailers; d) evaluate congruity of existing organization structure visà-vis diseconomies of scale and firm's sustainability; e) analyze recommendations from previous research studies appropriate in the Indian context; f) design a rational OS that would help lifestyle retailers in India overcome diseconomies of scale and protect firm's sustainability; vii) test the ROLS-b framework in a real retail environment; viii) evaluate test results, findings, and insights.

\section{APPROACH AND METHODOLOGY :}

Secondary Research: Intense and in-depth analysis of data available in the public domain was carried to collect data relating to various aspects of lifestyle retailing in India through company websites, company annual financial reports, Government database, trade, and business journals. Research works relating to Indian lifestyle retailers and retailing were surveyed extensively to collect insights, recommendations, and frameworks to understand their existing OS, economies of scale, and firm sustainability in addition to an extensive review of theories, frameworks, and models available in the literature.

Qualitative Primary Research: Series of open-ended direct interviews were conducted with employees selected through convenience sampling representing different departments/functions of select lifestyle retailers in India to understand their perspective and attitude towards existing OS, economies of scale, diseconomies of scale, and firm's sustainability.

Quantitative Primary Research: In the first stage, ten organized lifestyle retailers in India were selected who can represent, a) different product categories such as fashion, functional, life-stage specific, productspecific, gender-specific, and need specific products; b) offering single-product category and multiple- 
product categories; c) serving different consumer target groups at low, mid-low, mid, mid-high, high, and premium price positioning; d) having single and multiple stores; e) offering single brand and multiple brands; f) having presence across Tier-1, Tier-2, and Tier-3 cities; g) having stores across the high street, malls, institutions, and neighborhoods, h) organizational forms, and i) new and established retail store image. The second stage was to evaluate the last 5 years' overall performance of firms. In the third stage, 25 percent of the stores of one of the lifestyle retailers in the study were selected through systematic random sampling to undergo experimentation wherein the proposed ROLS-b framework was applied for twelve months'. In the fourth stage, all the data was collected before experimentation from all the stores belonging to the control and experimental group. The fifth stage was to collect post-test data from the control and experimental group of stores and in the last stage the collected data from pre and post-tests periods were subjected to various statistical analyses and inferences were drawn.

\section{EVALUATING EXISTING ORGANIZATIONAL STRUCTURE :}

Qualitative: Before the empirical study, we were able to derive qualitative insights by conducting openended direct interviews with employees representing all the departments/functions of different types of lifestyle retailers chosen for the study. Chart 1 captures OS commonly adopted by the brick-and-mortar lifestyle retailers in the study. The qualitative exploratory survey indicates that their existing OS has many gaps that were leading to diseconomies of scale and deteriorating the firm's profitability as listed below.

a) Chief Executive Officer (CEO) or Managing Director (MD) had retained a majority of decision-making authorities across departments and functions in the OS (Gap 1).

b) None of the functional heads $(\mathrm{FH})$ were authorized to make strategic-level decisions and they were limited to only tactical-level decision making (Gap 2).

c) Each FHs were specialists in their area and communication efficiency (conversations-for-action among them was merely dependent on relationship and understanding among them (Gap 3).

d) All the FHs were horizontally integrated into the OS (Gap 4) with every function in the OS being vertically integrated with department heads $(\mathrm{DH})$ who have sub-specialization required for the function.

e) Due to horizontal integration among FHs the coordination among DHs of various functions and the efficiency of communication (conversations-for-action) was dependent on the relationship and understanding among their respective FHs (Gap 5).

f) Except for CEO/MD, none of the employees across the hierarchy in the OS had KRAs and KPIs that would measure the contribution of each employee towards the long-term sustainability of the firm (Gap 6).

g) A majority of KRAs and KPIs of employees were focussed on measuring /penalizing/ rewarding them based on their functional/department level deliverables in silos (Gap 7).

h) Employees of Sales and Store Operations (SSO) function who was the face of the firm to consumers and generate revenue for the firm were completely dependent on actions of FHs, DHs, and employees of other functions and departments in the OS (Gap 8).

i) $\mathrm{FH}$ of $\mathrm{SSO}$ was the only one in the OS responsible for generating revenue and profit for the firm and ensure generating revenue that would take care of a majority of operating expenses of the firm (Gap 9).

j) The majority of CEO/MD's time was spent on balancing relationships and communication issues among FHs (Gap 10).

k) A majority of actions taken by Non-SSO functions were not understood by the SSO team members thereby forcing them to distance from owning the results of such actions (Gap 11).

1) The word development was only limited to the title of Human Resource Development (HRD) function and had little or no contribution towards the overall development of employees across the OS (Gap 12).

m) The majority of HRD team time was spent on monthly payroll processing, recruitment, and conducting annual performance evaluation/appraisal (Gap 12).

n) Training as a task was just a 'tick-in-the-box' activity for HRD (Gap 13). 
o) A majority of strategy-making, decision-making, planning, actions, and control across '4P's' of Marketing Mix were made by the employees of Non-SSO functions but the ownership of results was completely shifted onto SSO function (Gap 14).

In summary, a majority of lifestyle retailers in the study were unaware of the role of OS in conquering diseconomies of scale and protecting long-term firm's sustainability. The existing OS was indirectly forcing the retailers toward diseconomies of scale, besides, slowly losing their interest in the firm and confidence in the brick-and-mortar retailing model as a whole (Gap 15). All the 15 gaps identified during the exploratory qualitative primary research have been checked against the existing literature and shown in table 1.

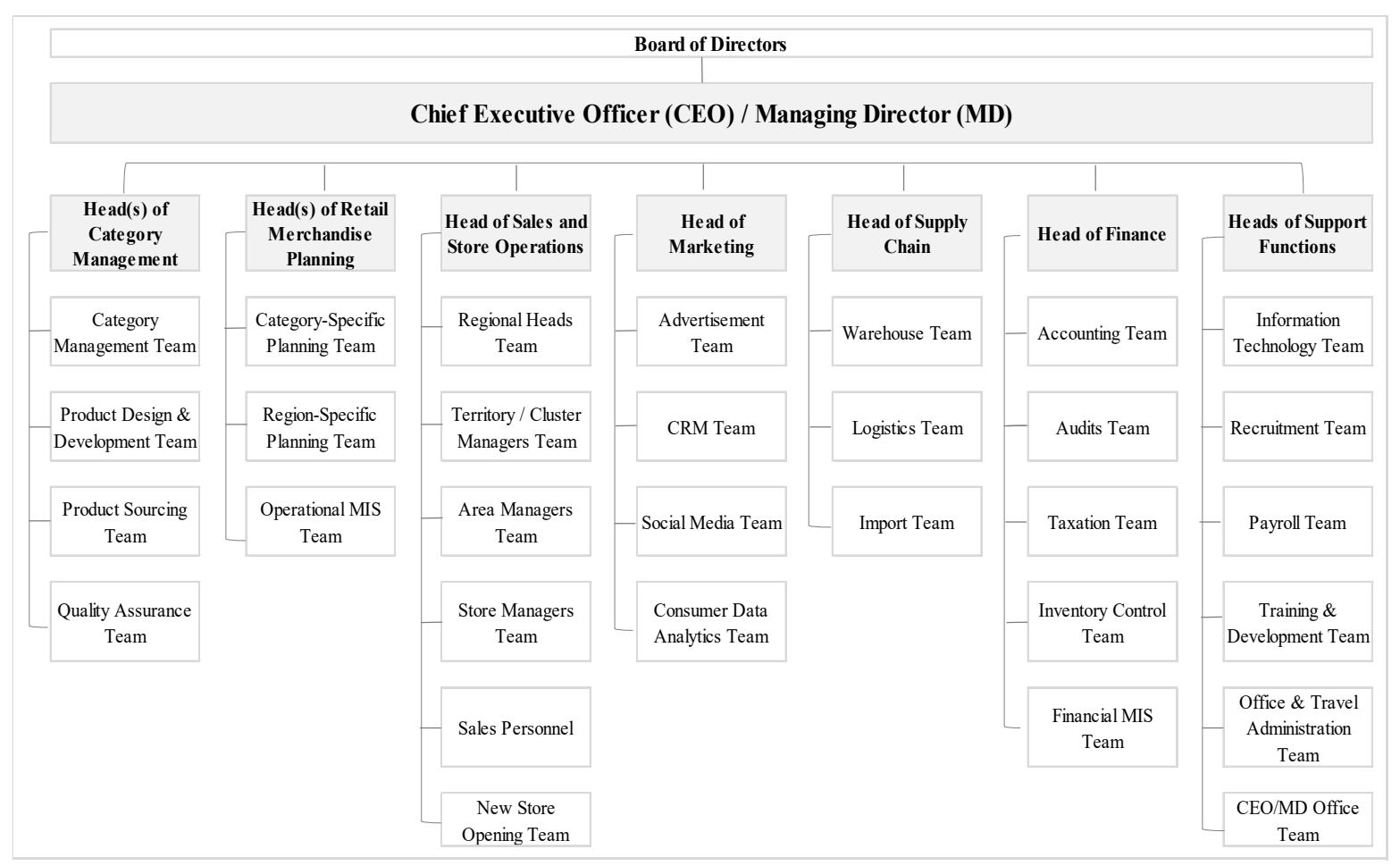

Chart 1: Existing organizational structure

Empirical: Evaluating the last five years data of lifestyle retailers in the study as shown in table 2 and chart 2 indicates that the firm-level profitability did not improve despite 117 percent increase in the store count over five years in addition to not bringing any economy of scale advantages to firms. The glaring observation was that the store count was significantly and negatively associated (R: -0.688 with a 2-tailed sig value of 0.003) with the firm-level profitability, whereas the association with the store-level profitability was insignificant (R: -0.037 with 2-tailed sig value of 0.005 ). In other words, these associations were corroborating to the key hypothesis of our study, that is, any economies of scale that is expected by the expansion of store counts would be lost if the OS is not rational and could also lead to diseconomies of scale in addition to affecting firm's long-term sustainability. 
International Journal of Management, Technology, and Social Sciences (IJMTS), ISSN: 2581-6012, Vol. 5, No. 2, August 2020.

Table 1: Mapping gaps identified in the qualitative research with existing literature

\begin{tabular}{|c|c|c|c|}
\hline S. No. & $\begin{array}{l}\text { Le ading to } \\
\text { Dis economies of } \\
\text { Scale }\end{array}$ & $\begin{array}{l}\text { Affecting Firm's } \\
\text { Sus tainability }\end{array}$ & Conformity with the Lite rature \\
\hline Gap 1 & $\checkmark$ & $\checkmark$ & {$[7],[8],[29],[35],[57],[59],[61]$} \\
\hline Gap 2 & $\checkmark$ & $\checkmark$ & $\begin{array}{c}{[7],[8],[9],[19],[29],[31],[35],[41],[51],[62],} \\
{[64],[65],[69],[72],[80],[81]}\end{array}$ \\
\hline Gap 3 & $\checkmark$ & $\checkmark$ & {$[7],[8],[14,[49],[57],[71],[80],[81]$} \\
\hline Gap 4 & $\checkmark$ & $\checkmark$ & $\begin{array}{c}{[7],[8],[14],[15],[17],[19],[20],[25],[26],[29],} \\
{[30],[39],[62],[65],[69],[72]}\end{array}$ \\
\hline Gap 5 & $\checkmark$ & $\checkmark$ & $\begin{array}{c}{[7],[8],[14],[23],[26],[37],[38],[39],[40],[41],} \\
{[25],[64],[80]}\end{array}$ \\
\hline Gap 6 & $\checkmark$ & $\checkmark$ & $\begin{array}{c}{[7],[8],[19],[25],[26],[34],[32],[47],[70],[77],} \\
{[78],[79]}\end{array}$ \\
\hline Gap 7 & $\checkmark$ & $\checkmark$ & {$[7],[8],[34],[32],[47],[70],[77],[78],[79]$} \\
\hline Gap 8 & $\checkmark$ & $\checkmark$ & $\begin{array}{c}{[7],[8],[16],[17],[23],[32],[40],[75],[76],[82],} \\
{[83],[84]}\end{array}$ \\
\hline Gap 9 & $\checkmark$ & $\checkmark$ & {$[7],[8],[20],[21],[25],[26],[41],[77]$} \\
\hline Gap 10 & $\checkmark$ & $\checkmark$ & $\begin{array}{c}{[7],[8],[17],[22],[26],[27],[32],[55],[58],[62],} \\
{[65],[66]}\end{array}$ \\
\hline Gap 11 & $\checkmark$ & $\checkmark$ & {$[7],[8],[25],[40],[41],[77]$} \\
\hline Gap 12 & $\checkmark$ & $\checkmark$ & {$[7],[8],[48],[51],[57],[63],[65],[71]$,} \\
\hline Gap 13 & $\checkmark$ & $\checkmark$ & {$[7],[8],[64],[65],[73],[74]$} \\
\hline Gap 14 & $\checkmark$ & $\checkmark$ & {$[7],[8],[17],[22],[31],[32],[47],[81]$} \\
\hline Gap 15 & $\checkmark$ & $\checkmark$ & {$[7],[8],[25],[29],[51],[52],[53],[62]$} \\
\hline
\end{tabular}

Table2: Association among store counts, economies of scale, and the firm's overall performance

\begin{tabular}{|c|c|c|c|c|c|c|c|c|c|c|c|}
\hline \multirow[t]{2}{*}{ Year } & \multirow{2}{*}{$\begin{array}{l}\text { Growth in } \\
\text { Store } \\
\text { Count } \\
\text { (year on } \\
\text { year) }\end{array}$} & \multicolumn{2}{|c|}{ Headcount Mix } & \multicolumn{2}{|c|}{ Salary Mix } & \multicolumn{2}{|c|}{$\begin{array}{c}\text { Salary as } \\
\text { Percentage of } \\
\text { Revenue }\end{array}$} & \multicolumn{2}{|c|}{$\begin{array}{c}\text { Salary as } \\
\text { Percentage of } \\
\text { Overall } \\
\text { Expenses }\end{array}$} & \multicolumn{2}{|c|}{$\begin{array}{c}\text { Retail Profit as } \\
\text { Percentage of } \\
\text { Revenue }\end{array}$} \\
\hline & & Non-SSO & SSO & Non-SSO & SSO & Non-SSO & SSO & Non-SSO & SSO & $\begin{array}{c}\text { Firm } \\
\text { Level }\end{array}$ & $\begin{array}{c}\text { Store } \\
\text { Level }\end{array}$ \\
\hline 1 & $21.43 \%$ & $14.07 \%$ & $85.93 \%$ & $57.50 \%$ & $42.50 \%$ & $7.41 \%$ & $10.78 \%$ & $11.96 \%$ & $6.88 \%$ & $-14.65 \%$ & $-6.69 \%$ \\
\hline 2 & $15.29 \%$ & $13.91 \%$ & $86.09 \%$ & $47.16 \%$ & $52.84 \%$ & $7.09 \%$ & $10.99 \%$ & $15.18 \%$ & $7.16 \%$ & $-11.79 \%$ & $-9.60 \%$ \\
\hline 3 & $27.55 \%$ & $15.91 \%$ & $84.09 \%$ & $52.11 \%$ & $47.89 \%$ & $6.93 \%$ & $12.36 \%$ & $15.08 \%$ & $7.86 \%$ & $-14.83 \%$ & $-7.58 \%$ \\
\hline 4 & $8.00 \%$ & $16.72 \%$ & $83.28 \%$ & $43.92 \%$ & $56.08 \%$ & $7.16 \%$ & $10.40 \%$ & $15.68 \%$ & $6.89 \%$ & $-8.20 \%$ & $-0.67 \%$ \\
\hline 5 & $12.59 \%$ & $15.21 \%$ & $84.79 \%$ & $40.23 \%$ & $59.77 \%$ & $8.28 \%$ & $10.59 \%$ & $16.58 \%$ & $6.67 \%$ & $-15.14 \%$ & $-8.58 \%$ \\
\hline
\end{tabular}




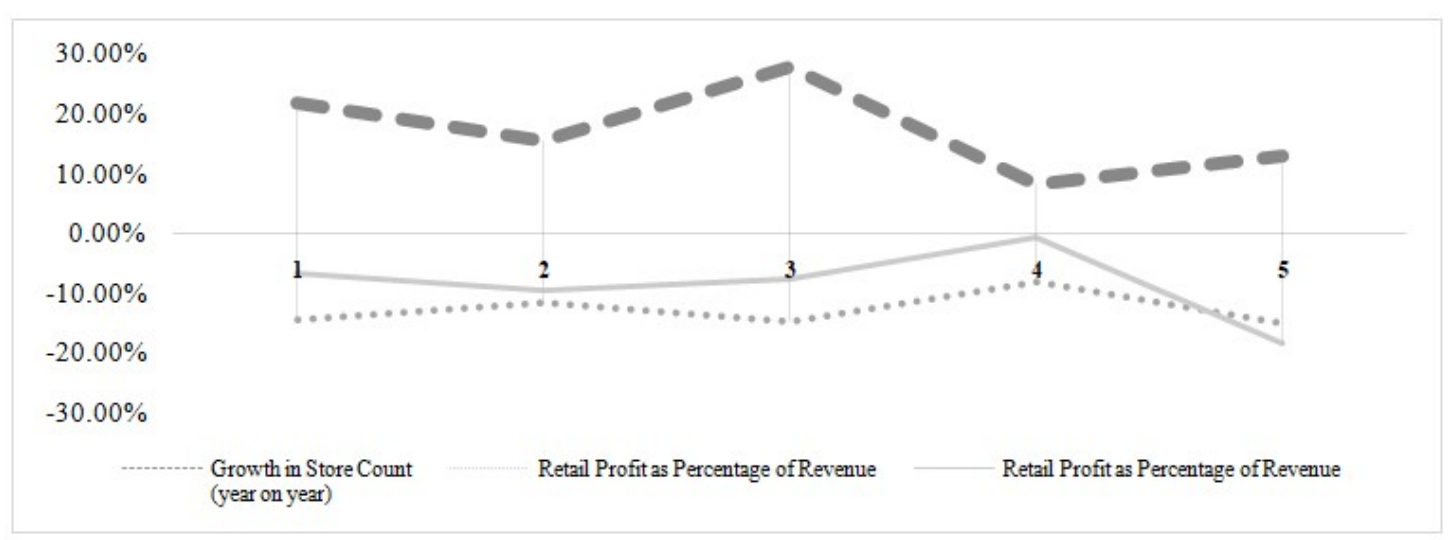

Chart 2: Association among store counts, economies of scale, and the firm's overall performance

Existing literature, exploratory qualitative primary finding, and empirical evaluation indicate that the existing OS of select organized brick-and-mortar lifestyle retailers in India is irrational as it seriously fails to gain economies of scale and protect firm's long-term sustainability expected due to expansion in addition to inducing loss of motivation and interest among all the stakeholders in the brick-and-mortar lifestyle retailing model. This brings us to the key research problem as to a) is there a different way to approach the OS, and if yes b) what could be a rational OS to overcome diseconomies of scale and protect the firm's long-term sustainability. Considering recommendations from past studies and insights from this study we would now attempt to design a rational OS for organized brick-and-mortar lifestyle retailers in India.

\section{DEVELOPMENT OF ROLS-b :}

Both qualitative and empirical findings unanimously indicate that the existing OS of select lifestyle retailers is predominantly skewed in favor of the Non-SSO functions concerning 'authority' while the majority of 'responsibilities' concerning overall firm's performance being loaded on to SSO function thereby creating a significant imbalance in the OS. It is a universally known phenomenon that an OS must ensure 'balanced authority-and-responsibility' across all the levels in the hierarchy irrespective of being integrated vertically or horizontally [85]. The key approach while designing the ROLS-b was to i) identify elements in the existing OS that are creating major gaps leading to diseconomies of scales and unsustainability of the firm; ii) find theories, models, and frameworks that provide a solution in filling such gaps; iii) eliminate as many gaps as possible to create a new OS design. Important changes that are adopted in the ROLS-b as depicted in chart 3(a) are;

A. Functional-Level Integration: The level of horizontal integration among various functions was significantly reduced i.e., seven functions that were functioning independently, and reporting to the CEO/MD was regrouped and reduced to three functions.

B. Balancing Authority-and-Responsibility: Regrouping of many functions and sub-functions under the 'SSO' function that plays an important role in generating loyal consumers, revenue, and profit in addition to being one of the major functions in a brick-and-mortar retail organization that takes a larger share in the capital and recurring expenses. A majority of functions and sub-functions were regrouped under the 'Finance' function that is required to be independent of other functions. Another function that was kept independent of SSO and Finance functions was 'Human Resource Development' (HRD) function as the same is also expected to have enough authority while ensuring common goals of the organizations are achieved through healthy organizational culture.

C. Decentralization: A rational OS must integrate and balance authority-and-responsibility across all the levels in the hierarchy. The ROLS-b while regrouping functions has also incorporated regrouping of departments. Chart 3(b) indicates the extended OS of Regional SSO department that is one of the most important departments under the SSO function. The Regional SSO department being one of the closest 
departments to the consumer has been allotted with specialists from different functions and sub-functions to ensure real-time support, control, removal of roles that were duplications, and systematic empowerment to deal with dynamic changes in the market environment.

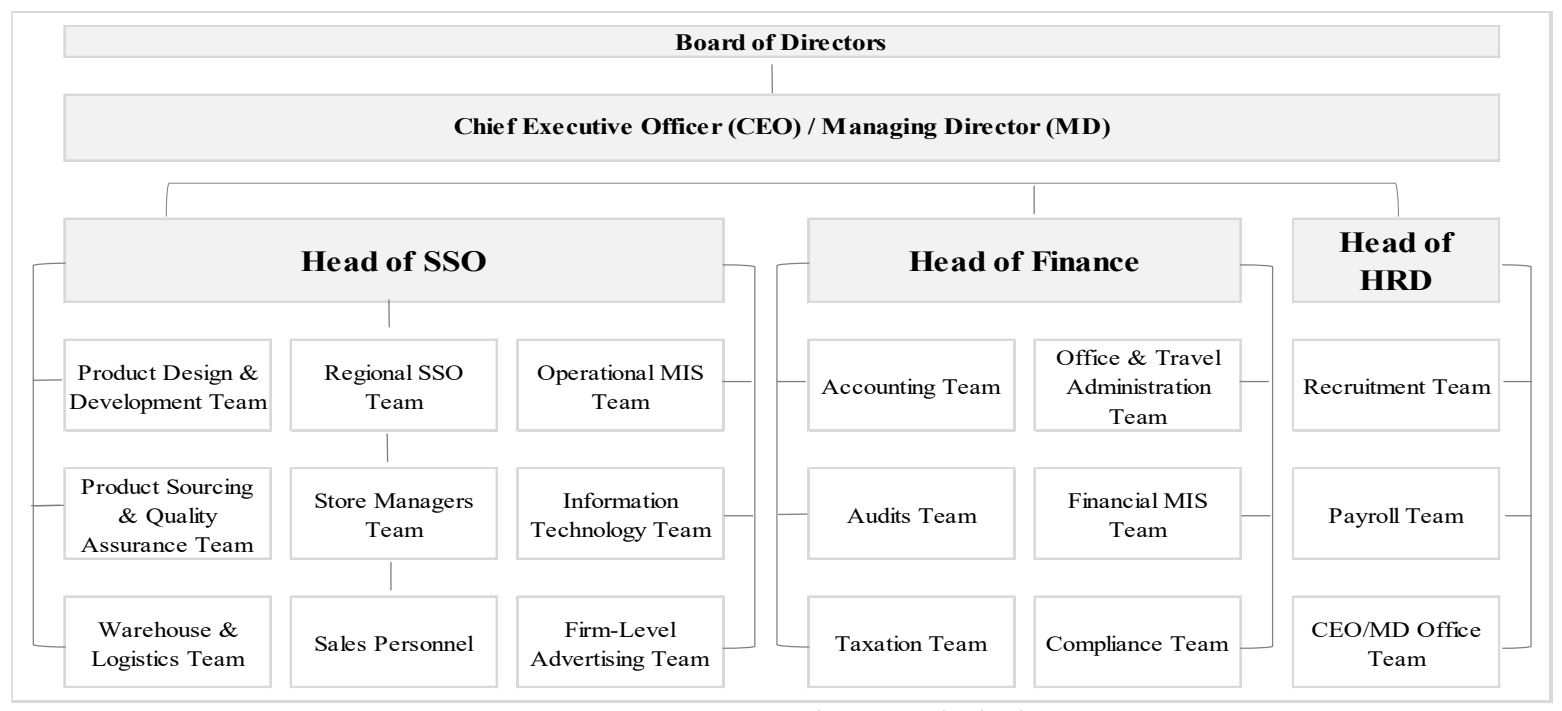

Chart 3(a): Proposed ROLS-b design

All the changes $\mathrm{A}, \mathrm{B}$, and $\mathrm{C}$ are expected to eliminate gaps that lead to diseconomies of scale such as excessive rigidity; unexplained wage differential; insularity; R\&D cost control; alienation; low job satisfaction; insularity from reality; monitoring costs and inadequate effort levels; cost-consciousness; low motivation levels; risk aversion; increase in administration; poor understanding of changing market needs; perpetuation of organization form; low productivity by the R\&D; limits to entrepreneurship; weaker incentives in bureaucracies; specialization leading to poor communication; information loss; communication losses; poor coordination levels; information signal delays; lower efficiency levels; control-loss in addition to improvising elements that are responsible for long-term sustainability of a firm such as the role of human resource development; creativity and innovations that are consumer-centric; situational leadership style; organizational capabilities; positive stakeholder influences; business practices; ability to face changing market environments; effective conversations-for-action; attention to strategic change; management capabilities to efficiently use resources (physical, human and financial); leadership effectiveness; rightsizing of human resources; leadership styles; competitive dynamics and strategic consistency; humanistic and ethical approaches beyond economic criteria; favorable employee attitudes; favorable relationships between the people inside and outside the organisation; perspectives of people in the bottom of the hierarchy on people above them in the hierarchy; positive response to switch leadership; strategic planning capabilities; reputation building; control-self assessment; organizational culture; market-orientation; relevant training; sales personnel empowerment; need-based sales pitch by the sales personnel; performance evaluation systems; customization level of consumer communications; consumer orientation; store image. 


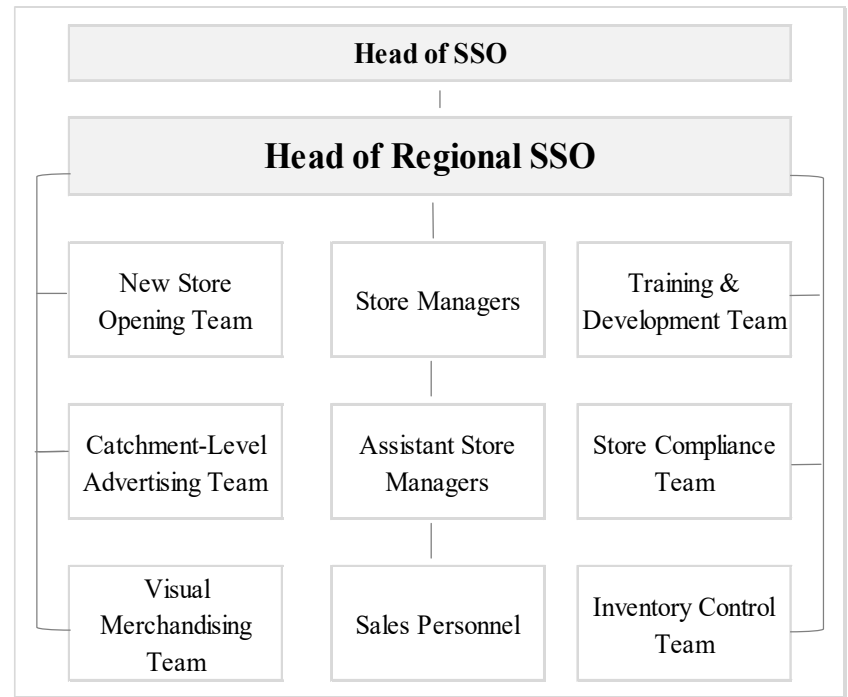

Chart 3(b): Regional organizational structure under ROLS-b design

\section{TESTING OF ROLS-b DESIGN :}

We were firm in our approach that, the proposed ROLS-b design has to be tested in a retail set up before we recommend the same to brick-and-mortar lifestyle retailers in India. But it was not that easy merely because of the vast scope of the experiment. Unlike other experiments wherein the treatment is limited to few concepts, components or variables this experiment required us to practically cover almost all the elements of an organizational design which do require longer duration for preparations before testing, longer duration before the beginning of extracting the results and a longer period for the experimentation itself to ensure findings and insights are derived holistically. The biggest challenge of testing the new ROLS-b design was the time taken to make attitudinal changes in the employees of the select retailer across all departments and functions. The attitude of employees in the higher levels of hierarchy towards the ROLS-b design was significantly negative while the employees in the lower levels were encouraged by the new OS. We were cognizant and it was inevitable that such significantly negative beliefs are addressed to ensure the testing of proposed ROLS-b design has buy-in from the majority of the employees across functions, departments, and levels. Thus, we decided to undertake a series of training before experimentation. Out of many lifestyle retailers in the study, we selected one retailer and started applying new ROLS-b design to one complete Region (experimental group) that represents 25 percent of the overall store count of the select retailer in phases applying treatment element by element one after the other over six months be it regrouping of functions, regrouping of sub-functions, and modifying the performance evaluation methods before heading to record results of the experiment. Once we have completed treatment across all the elements recommended by the proposed ROLS-b design, we took the final reading of resultant data to further analyze, evaluate, and derive insights for an entire 12 months' period.

\section{KEY FINDINGS AND INSIGHTS FROM THE EXPERIMENT :}

We have recorded results of data analysis independently for empirical and qualitative as detailed in this section to ensure that we take an unbiased look at each of these findings before we consolidate all the results to conclude.

Empirical Analysis: Pre-test post-test real treatment effect has shown an increase in the headcount mix, salary mix, salary as a percentage of revenue generated and salary as a percentage of overall retail expenses of SSO function and a decrease of all these parameters in the Non-SSO functions in addition to a significant and positive real treatment impact on the overall store-level and firm-level profitability in the experimental group of stores that was expected by the ROLS-b as shown in table 3. 
Table 3: Pre-test post-test real treatment effect across key factors in the experimental group as a percentage change over their pre-test period

\begin{tabular}{|l|c|}
\hline Particulars & $\begin{array}{c}\text { Post-Test } \\
\text { Experimental } \\
\text { Group }\end{array}$ \\
\hline Headcount Mix - SSO & $9.7 \%$ \\
\hline Headcount Mix - Non-SSO & $-54.0 \%$ \\
\hline Salary Mix - SSO & $30.5 \%$ \\
\hline Salary Mix - Non-SSO & $-45.3 \%$ \\
\hline Salary as Percentage of Revenue - SSO & $93.7 \%$ \\
\hline Salary as Percentage of Revenue - Non-SSO & $-49.6 \%$ \\
\hline Salary as Percentage of Overall Expenses - SSO & $69.1 \%$ \\
\hline Salary as Percentage of Overall Expenses - Non-SSO & $-76.4 \%$ \\
\hline Retail Profit as Percentage of Revenue - Store Level & $502.6 \%$ \\
\hline Retail Profit as Percentage of Revenue - Firm Level & $118.2 \%$ \\
\hline
\end{tabular}

Pre-test post-test real treatment effect has also shown a significant improvement in the absolute revenue generation, contribution to the overall firm's revenue, absolute gross earnings generation, contribution to the overall firm's gross earnings, store-level retail profit, firm-level retail profit, and most importantly consumer repeat store visit rate in addition toa significant reduction in the firm-level advertisement costs, warehouse and logistics costs and a significant increase in the Regional SSO employee cost and catchment-level advertisement costs that was expected by the ROLS-b in the experimental group of stores as shown in table 4.

Table 4: Pre-test post-test real treatment effect across key factors in the experimental group as a percentage change over their pre-test period

\begin{tabular}{|l|c|}
\hline Factors & $\begin{array}{c}\text { Post-Test } \\
\text { Experimental } \\
\text { Group }\end{array}$ \\
\hline Consumer Repeat Store Visit Rate & $96.17 \%$ \\
\hline Revenue & $62.00 \%$ \\
\hline Revenue Contribution & $67.01 \%$ \\
\hline Gross Earnings & $83.21 \%$ \\
\hline Gross Earnings Contribution & $54.79 \%$ \\
\hline Store Expenses & $-2.82 \%$ \\
\hline Regional SSO Employee Cost & $99.44 \%$ \\
\hline Warehouse and Logistics Cost & $-38.92 \%$ \\
\hline Firm-Level Advertisement Cost & $-1396.98 \%$ \\
\hline Catchment-Level Advertisement Cost & $40.04 \%$ \\
\hline Retail Profit (Store-Level) & $196.64 \%$ \\
\hline Retail Profit (Firm-Level) & $67.54 \%$ \\
\hline
\end{tabular}

Tables 5 demonstrate the magnitude of change in the key parameters of the experimental group of stores during pre-test and post-test periods over the control group of stores. One can observe an increase in the headcount mix, salary mix, salary as a percentage of revenue generated and salary as a percentage of overall retail expenses of SSO function and a decrease of all these parameters in the Non-SSO functions in addition to a significant and positive improvement in the overall store-level and firm-level profitability in the post-test period. 
Table 5: Percentage variance between experimental and control group during pre and post-test periods across key factors

\begin{tabular}{|l|c|c|}
\hline Particulars & $\begin{array}{c}\text { Pre-Test } \\
\text { Experimental } \\
\text { Group }\end{array}$ & $\begin{array}{c}\text { Post-Test } \\
\text { Expe rimental } \\
\text { Group }\end{array}$ \\
\hline Headcount Mix - SSO & $0.0 \%$ & $9.7 \%$ \\
\hline Headcount Mix - Non-SSO & $0.0 \%$ & $-54.0 \%$ \\
\hline Salary Mix - SSO & $0.0 \%$ & $30.5 \%$ \\
\hline Salary Mix - Non-SSO & $0.0 \%$ & $-45.3 \%$ \\
\hline Salary as Percentage of Revenue - SSO & $-40.8 \%$ & $14.7 \%$ \\
\hline Salary as Percentage of Revenue - Non-SSO & $0.0 \%$ & $-49.4 \%$ \\
\hline Salary as Percentage of Overall Expenses - SSO & $0.0 \%$ & $69.1 \%$ \\
\hline Salary as Percentage of Overall Expenses - Non-SSO & $0.0 \%$ & $-76.4 \%$ \\
\hline Retail Profit as Percentage of Revenue - Store Level & $-66.5 \%$ & $1651.4 \%$ \\
\hline Retail Profit as Percentage of Revenue - Firm Level & $-29.0 \%$ & $1719.6 \%$ \\
\hline
\end{tabular}

Tables 6 demonstrate the magnitude of change in the key factors of the experimental group of stores during pre-test and post-test periods over the control group of stores. One can observe a significant improvement in the absolute revenue generation, absolute gross earnings generation, store-level retail profit, firm-level retail profit, and most importantly consumer repeat store visit rate in the post-test period.

Table 6: Percentage variance between experimental and control group during pre and post-test periods across key factors

\begin{tabular}{|l|c|c|}
\hline Factors & $\begin{array}{c}\text { Pre-Test } \\
\text { Experimental } \\
\text { Group }\end{array}$ & $\begin{array}{c}\text { Post-Test } \\
\text { Experimental } \\
\text { Group }\end{array}$ \\
\hline Consumer Repeat Store Visit Rate & $219.08 \%$ & $502.17 \%$ \\
\hline Revenue & $2.61 \%$ & $42.95 \%$ \\
\hline Gross Earnings & $3.65 \%$ & $36.75 \%$ \\
\hline Regional SSO Employee Cost & $34.95 \%$ & $219.67 \%$ \\
\hline Retail Profit (Store-Level) & $-82.99 \%$ & $203.48 \%$ \\
\hline Retail Profit (Firm-Level) & $-56.64 \%$ & $380.64 \%$ \\
\hline
\end{tabular}

Qualitative Analysis: As far as qualitative findings are concerned an open-ended interview was conducted with select (convenience) employees across SSO and Non-SSO functions and departments in the experimental group of stores. Results indicate that the ROLS-b was able to improve flexibility in administration; cost-consciousness; job satisfaction; motivation levels; calculated risk-taking capabilities; understanding of changing market needs in real-time; productivity levels; sense of entrepreneurship; incentive earnings; quality of communication; clarity of communication; coordination levels; efficiency levels; relevancy of training and development contents; creativity and innovations specific to a particular store; organizational capabilities; stakeholder interest; effective conversations-for-action; rightsizing of human resources relevant for SSO functioning; positive employee attitudes towards the firm; positive relationships between the people inside and outside the firm; perspectives of people in the bottom of the hierarchy on people above them in the hierarchy; tactical planning capabilities; organizational culture; market-orientation; sales personnel empowerment; customization level of consumer communications; store image in the consumer's minds and most importantly level of consumer-orientation and ownership of every action. 


\section{CONCLUSION :}

The theory of diseconomies of scale conceptualized by Coase [7] and Williamson [8-9] in the years 1937 and 1975 respectively that was mostly skewed to manufacturing setups also holds for the service industry i.e., brick-and-mortar retailing in India even today. In addition to the theory of diseconomy of scale another theory that still holds concerning the OS of lifestyle retailers in India is Simon's theory of bounded rationality [12] and Neilson's argument on balancing authority-and-responsibility [85]. Firm's long-term sustainability is influenced by the OS of a firm that was argued by many studies in the past [48-72] also holds to brick-andmortar lifestyle retailing in India in addition to conforming results of our previous studies that are relevant to the context of this study [47, 74-85]. While designing the ROLS-b we have followed a logical mixture of these theories and studies in the literature and incorporated insights gained from the exploratory qualitative stage of this study that involved evaluating ten organized lifestyle retailers in India who represented, a) different product categories such as fashion, functional, life-stage specific, product-specific, gender-specific, and need specific products; b) offering single-product category and multiple-product categories; c) serving different consumer target groups at low, mid-low, mid, mid-high, high, and premium price positioning; d) having single and multiple stores; e) offering single brand and multiple brands; f) having presence across Tier-1, Tier-2, and Tier-3 cities; g) having stores across the high street, malls, institutions, and neighborhoods and $h$ ) new and established retail store image in addition to evaluating their last 5 years' overall performance. Once the ROLS-b was designed, we have experimented with the new OS on one of these ten lifestyle retailers to test the validity and reliability of ROLS-b. Experimentation results empirically and qualitatively demonstrate that the existing belief of brick-and-mortar lifestyle retailers in India which assumes economies of scale and long-term firm's sustainability as the retailer increases the store count is just a misconception and does not hold. Among many of the changes that were made to the existing OS to design the ROLS-b the most important elements were i) balancing authority-and-responsibility between SSO and Non-SSO functions/departments; ii) balancing horizontal and vertical hierarchical integrations; iii) systematic decentralization and empowerment of employees who manage the last-mile communications, and iv) inputsdriven performance evaluation methodologies. The ROLS-b design proposed in this study takes into consideration the complexity brick-and-mortar lifestyle retailing in India and we have attempted to reduce this complexity level to the best possible. When we experimented the ROLS-b for over twelve months at over 25 percent stores of a select retailer, results demonstrate that these stores which have gone through the treatment have shown 5.34 times improvement in the store-level profit and 1.97 times in the firm-level profit thereby providing validity and reliability of the proposed rational OS (ROLS-b) in the field.

\section{SUGGESTIONS :}

The sustainable success of a brick-and-mortar lifestyle retailer in India significantly depends on the trueness level of their image that is carried in employees, investors, competitors, and consumers' minds and not the revenue or profit they generate [86-88]. To ensure a lifestyle retailer gets a true lifestyle image, they need to think beyond revenue, profit, and even store count which is what has to be the main criteria while designing the OS. Unless a retailer adopts an OS that ensures an optimal level of market and consumer-orientation, it is unlikely that the retailer will ever be able to create a positive image in consumer's minds in addition to creating a higher number of consumers with high levels of patronage with their stores. Lifestyle retailers in India also need to clearly understand every other lifestyle retailer's key business objective and their organizational form behind adopting certain OS. Every investor has different business goals and motives while entering into lifestyle retailing and as long as you intend to gain a true lifestyle retailer image in the consumer's mind then we recommend you adopt an OS that is similar to ROLS-b and would help you overcome diseconomies of scale and protect the long-term sustainability of your firm economically in addition to integrating social and environmental interest.

\section{LIMITATIONS OF RESEARCH :}

The main limitation of this research work is the coverage of various stakeholders viz., the number of lifestyle 
retailers, product categories, consumer groups, employees, investor types, organizational forms, and price positioning while designing the recommended ROLS-b. This might limit the generalizability of research findings to other sets of lifestyle retailers. The second limitation would be that the empirical validation is restricted to a few lifestyle retailers selected for the study and hence the generalizability of the findings and suggestions to other lifestyle retailers in India. The third limitation would be our ability to carry out true experimental design, at best we were able to carry out a pre-test post-test control group experimental design. However, it provides significant inputs regarding the ways to utilize these findings as all the findings have been derived from an experiment spread over twelve months' on a larger sample in addition to incorporating recommendations of proven theories in the literature.

\section{SCOPE FOR FURTHER RESEARCH :}

We strongly recommended that the ROLS-b is used by researchers to further test its validity and reliability in addition to finetuning it further if required for lifestyle or non-lifestyle retailers. Based on short-term and long-term the key business objectives of lifestyle retailers, the ROLS-b ramework can be used as a basic tool while designing OS and finetune the same suitably.

\section{REFERENCES :}

[1] https://www.amazon.in/b/?ie=UTF8\&node=6648217031\&ref_=topnav_storetab_top_ap_mega. Retrieved in August 2020.

[2] Schmitt, B. (2012). The consumer psychology of brands. Journal of Consumer Psychology.22 (1): 7-17.

[3] http://www.technopak.com/Files/fashion-retail-scenario-in-india.pdf. Retrieved in August 2020.

[4] http://statisticstimes.com/demographics/population-of-india.php. Retrieved in August 2020.

[5] https://www.mckinsey.com/industries/retail/our-insights/the-state-of-fashion-2019-a-year-ofawakening. Retrieved in August 2020.

[6] https://www2.deloitte.com/content/dam/Deloitte/in/Documents/consumer-business/in-consumer-RLS2019-noexp.pdf. Retrieved in August 2020.

[7] Coase, R. H. (1937). The Nature of the Firm. Economica, New Series, 4(16), 386-405.

[8] Williamson, O. E. (1967). Hierarchical Control and Optimum Firm Size. Journal of Political Economy, $75(2), 123-138$.

[9] Williamson, O. E. (1967). Markets and Hierarchies: Analysis and Antitrust Implications. New York: Free Press, 126-137.

[10] Williamson, O. E. (1993). Opportunism and Its Critics. Managerial and Decision Economics, 14(2), 97-107.

[11] Riordan, M. H. \& Williamson, O. E. (1985). Asset specificity and economic organization. International Journal of Industrial Organization, 3(4), 365-378.

[12] Simon, H. A. (1947). 1976. Administrative Behavior. 3d ed. New York: Free Press. Original edition, New York: Macmillan, pp. 26-31.

[13] Simon, H. A. (2000). Barriers and bounds to Rationality. Structural Change and Economic Dynamics, $11(1-2), 243-253$.

[14] Arrow, K. J. (1974). The Limits of Organization. New York, Norton, p 33.

[15] Blau, P. M. \& M. W. Meyer. (1987). Bureaucracy in Modern Society. 3d ed. New York, McGraw-Hill, pp 139-167. 
[16] Brown, C., Hamilton, J. \& J. Medoff. (1990). Employers Large and Small. Cambridge, Harvard University Press, p 42.

[17] Child, J. (1973). Predicting and Understanding Organization Structure. Administrative Science Quarterly, 18(2), 168-185.

[18] Cooper, A. C. (1964). R\&D Is More Efficient in Small Companies. Harvard Business Review, 42 (MayJune), 75-83.

[19] Crozier, M. (1964). The Bureaucratic Phenomenon. Chicago, University of Chicago Press.

[20] Scherer, F. M. (1976). Industrial structure, scale economies, and worker alienation. Essays on industrial organization in honor of Joe S. Bain, 105-122.

[21] Merton, R. K. (1957). Social Theory and Social Structure. Revised and enlarged ed. Glencoe, III, Free Press, pp. 197-200.

[22] Pugh, D. S., Hickson, D. J., Hinings, C. R. \& Turner, C. (1969). The context of organization structures. Administrative science quarterly, March, 91-114.

[23] Qian, Y. (1994). Incentives and loss of control in an optimal hierarchy. The Review of Economic Studies, 61(3), 527-544.

[24] Schmookler, J. (1972). The size of firm and the growth of knowledge. Patents, invention, and economic change, $\mathrm{p} 39$.

[25] Schumacher, E. F. (1778). Small is beautiful: economics as if people mattered. London: Blond \& Briggs, p. 245.

[26] Brock, J. W. (1987). Bigness is the Problem, not the Solution. Challenge, 30(3), 11-16.

[27] Carroll, G. R. \& Hannan, M. T. (2004). The demography of corporations and industries. Princeton University Press, 289-290.

[28] Jensen, M. C. (1986). Agency costs of free cash flow, corporate finance, and takeovers. The American Economic Review, 76(2), 323-329.

[29] Monsen Jr, R. J. \& Downs, A. (1965). A theory of large managerial firms. Journal of Political Economy, 73(3), 221-236.

[30] Pondy, L. R. (1969). Effects of size, complexity, and ownership on administrative intensity. Administrative Science Quarterly, 14(1), 47-60.

[31] Stinchcombe, A. L. (2000). Social structure and organizations. Emerald Group Publishing Limited.

[32] Williamson, O. E. (1996). The mechanisms of governance. Oxford University Press, p 266.

[33] Peters, T. (1992). Rethinking scale. California Management Review, 35(1), 7-29.

[34] Rasmusen, E. \& Zenger, T. (1990). Diseconomies of scale in employment contracts. Journal of Law, Economics, and Organization, 6(1), 65-92.

[35] Silver, M. \& Auster, R. (1969). Entrepreneurship, profit, and limits on firm size. The Journal of Business, 42(3), 277-281.

[36] Zenger, T. R. (1994). Explaining organizational diseconomies of scale in R\&D: Agency problems and the allocation of engineering talent, ideas, and effort by firm size. Management Science, 40(6), 708-729.

[37] Arrow, K. J. (1983). Innovation in large and small firms. In Entrepreneurship, Lexington Books, Lexington, Ma, 15-28. 
[38] Barnard, C. I. (1968). The functions of the executive (Vol. 11). Harvard university press, p 110.

[39] Geanakoplos, J., \& Milgrom, P. (1991). A theory of hierarchies based on limited managerial attention. Journal of the Japanese and International Economies, 5(3), 205-225.

[40] McAfee, R. P. \& McMillan, J. (1995). Organizational diseconomies of scale. Journal of Economics \& Management Strategy, 4(3), 399-426.

[41] Mookherjee, D. \& Reichelstein, S. (2001). Incentives and coordination in hierarchies. The BE Journal of Theoretical Economics, 1(1), 1-38.

[42] Pugh, D. S. \& Pugh, D. S. (Eds.). (1971). Organization theory: Selected readings (Vol. 126). Harmondsworth: Penguin, 13-20.

[43] Ahmady, G. A., Mehrpour, M. \& Nikooravesh, A. (2016). OS. Procedia-Social and Behavioral Sciences, 230, 455-462.

[44] Bolman, L. G. \& Deal, T. E. (1991). Leadership and management effectiveness: A multi-frame, multisector analysis. Human Resource Management, 30(4), 509-534.

[45] Hatch, M. J. (2018). Organization theory: Modern, symbolic, and postmodern perspectives. Oxford university press.

[46] Wirtenberg, J., Harmon, J., Russell, W. G., \& Fairfield, K. D. (2007). HR's role in building a sustainable enterprise: Insights from some of the world's best companies. People and Strategy, 30(1), 10-20.

[47] Ganesha, H. R., Aithal, P. S. \& Kirubadevi, P. (2020). Integrated Marketing Mix Framework for Baby Care Retailing in India. International Journal of Applied Engineering and Management Letters (IJAEML), 4(1), 191-218.

[48] Rowden, R. W. (1995). The role of human resource development in successful small to mid-sized manufacturing businesses: A comparative case study. Human Resource Development Quarterly, 6(4), 355-373.

[49] Heunks, F. J. (1998). Innovation, creativity and success. Small Business Economics, 10(3), 263-272.

[50] Silverthorne, C. \& Wang, T. H. (2001). Situational leadership style as a predictor of success and productivity among Taiwanese business organizations. The Journal of Psychology, 135(4), 399-412.

[51] Rogers, M. (2004). Capabilities for sustainable business success. Australian Journal of Management, 29(1), 21-25.

[52] Pajunen, K. (2006). Stakeholder influences in organizational survival. Journal of Management Studies, 43(6), 1261-1288.

[53] Fabling, R. B. \& Grimes, A. (2007). Practice makes profit: Business practices and firm success. Small Business Economics, 29(4), 383-399.

[54] Pfeffer, J. (2007). What were they thinking?: Unconventional wisdom about management. Harvard Business Press.

[55] Dervitsiotis, K. N. (2002). The importance of conversations-for-action for effective strategic management. Total Quality Management, 13(8), 1087-1098.

[56] Smith, H. L., Discenza, R. \& Baker, K. G. (2005). Building sustainable success in art galleries: An exploratory study of adaptive strategies. Journal of Small Business Strategy, 16(2), 29-42.

[57] Kippenberger, T. (1998). Fresh perspectives on some original concepts. The Antidote, 37, 6-11.

[58] Fleck, D. L. (2009). Archetypes of organizational success and failure. BAR-Brazilian Administration 
Review, 6(2), 78-100.

[59] Gilley, A., Dixon, P. \& Gilley, J. W. (2008). Characteristics of leadership effectiveness: Implementing change and driving innovation in organizations. Human Resource Development Quarterly, 19(2), 153169.

[60] Chu, P. \& Siu, W. S. (2001). Coping with the Asian economic crisis: The rightsizing strategies of smalland medium-sized enterprises. International Journal of Human Resource Management, 12(5), 845-858.

[61] Idris, F., \& Mohd Ali, K. A. (2008). The impacts of leadership style and best practices on company performances: Empirical evidence from business firms in Malaysia. Total Quality Management, 19(12), 165-173.

[62] Lamberg, J. A., Tikkanen, H., Nokelainen, T., \& Suur-Inkeroinen, H. (2009). Competitive dynamics, strategic consistency, and organizational survival. Strategic Management Journal, 30(1), 45-60.

[63] Rosanas, J. M. (2008). Beyond economic criteria: A humanistic approach to organizational survival. Journal of Business Ethics, 78(3), 447-462.

[64] Thompson, J. W. (1996). Employee attitudes, organizational performance, and qualitative factors underlying success. Journal of Business and Psychology, 11(2), 171-196.

[65] Weymes, E. (2002). Relationships not leadership sustain successful organisations. Journal of Change Management, 3(4), 319-331.

[66] Longenecker, C. O., Simonetti, J. L., \& Sharkey, T. W. (1999). Why organizations fail: the view from the front-line. Management Decision, 37(6), 503-513.

[67] Prabhakar, G. P. (2005). Switch leadership in projects an empirical study reflecting the importance of transformational leadership on project success across twenty-eight nations. Project Management Journal, 36(4), 53-60.

[68] Distel, D., \& Myers, D. (2002). Leadership and strategic planning: Keys to success in a changing environment. In ASQ World Conference on Quality and Improvement Proceedings (p. 173). American Society for Quality.

[69] Goldberg, A. I., Cohen, G., \& Fiegenbaum, A. (2003). Reputation building: Small business strategies for successful venture development. Journal of Small Business Management, 41(2), 168-186.

[70] Sheffield, J., \& White, S. (2004). Control self-assessment as a route to organisational excellence. Managerial Auditing Journal, 19(4), 484-492.

[71] Meško Štok, Z., Markič, M., Bertoncelj, A., \& Meško, M. (2010). Elements of organizational culture leading to business excellence. Zbornik radova Ekonomskog fakulteta u Rijeci: časopis za ekonomsku teoriju i praksu, 28(2), 303-318.

[72] Küster, I., \& Vila, N. (2011). The market orientation-innovation-success relationship: The role of internationalization strategy. Innovation, 13(1), 36-54.

[73] Kempton, G. E. (1996). Training for organizational success. Health Manpower Management, 22(6), 2530.

[74] Ganesha, H. R., \& Aithal, P. S. (2020). Sales Personnel Training - An Integrated Framework for Indian Brick-and-Mortar Retailers. International Journal of Case Studies in Business, IT, and Education (IJCSBE), 4(1), 172-187.

[75] Ganesha, H. R., Aithal, P. S. \& Kirubadevi, P. (2020). Decentralized Discounting Framework: Insights from an Experiment. International Journal of Applied Engineering and Management Letters (IJAEML), 
$4(1), 20-40$.

[76] Ganesha, H. R., Aithal, P. S. \& Kirubadevi, P. (2020). Integrated Discounting Framework for Indian Brick-and-Mortar Retailers. International Journal of Management, Technology, and Social Sciences (IJMTS), 5(1), 110-123.

[77] Ganesha, H. R., Aithal, P. S. \& Kirubadevi, P. (2020). Need-Based Sales Pitch: Insights from an Experiment. International Journal of Case Studies in Business, IT, and Education (IJCSBE), 4(1), 7987.

[78] Ganesha, H. R., Aithal, P. S. \& Kirubadevi, P. (2020). Input and Output Driven Sales Personnel Performance Measures: Insights from an Experiment. International Journal of Case Studies in Business, $I T$, and Education (IJCSBE), 4(1), 23-37.

[79] Ganesha, H. R., \& Aithal, P. S. (2020). Retailing Performance Evaluation Scale for Indian Brick-andMortar Lifestyle Retailers (LSRS-b). International Journal of Applied Engineering and Management Letters (IJAEML), 4(1), 303-322.

[80] Ganesha, H. R., \& Aithal, P. S. (2020). Consumer Communication Deployment Tactics: An Integrated Framework for Lifestyle Brands and Retailers in India (CCF-LS). International Journal of Applied Engineering and Management Letters (IJAEML), 4(2), 1-21.

[81] Ganesha, H. R., \& Aithal, P. S. (2020). Organizing the Unorganized Lifestyle Retailers in India: An Integrated Framework. International Journal of Applied Engineering and Management Letters (IJAEML), 4(1), 257-278.

[82] Ganesha, H. R., Aithal, P. S. \& Kirubadevi, P. (2020). Consumer Affordability in Tier-1, Tier-2, and Tier-3 Cities of India - An Empirical Study. International Journal of Applied Engineering and Management Letters (IJAEML), 4(1), 156-171.

[83] Ganesha, H. R., Aithal, P. S. \& Kirubadevi, P. (2020). Ideal Store Locations for Indian Retailers - An Empirical Study. International Journal of Management, Technology, and Social Sciences (IJMTS), 5(1), 215-226.

[84] Ganesha, H. R., Aithal, P. S. \& Kirubadevi, P. (2020). Optimal Category Mix in Multi-Category Retailing - Insights from an Experiment. International Journal of Case Studies in Business, IT, and Education (IJCSBE), 4(1), 112-126.

[85] Neilsen, E. (1986). Empowerment strategies: Balancing authority and responsibility. Executive power, 78-110.

[86] Ganesha, H. R., \& Aithal, P. S. (2020). Establishing True Lifestyle Brand in India: An Integrated Marketing Mix Framework. International Journal of Management, Technology, and Social Sciences (IJMTS), 5(1), 261-284.

[87] Ganesha, H. R., \& Aithal, P. S. (2020). Measuring True Potential of Lifestyle Brands in India: A FirmLevel Scale for Existing and Potential Investors (FL-LBSi). International Journal of Applied Engineering and Management Letters (IJAEML), 4(1), 279-302.

[88] Ganesha, H. R. \& Aithal, P. S. (2020). Measuring True Potential of Lifestyle Brands in India: A Consumer-Level Scale for Existing and Potential Investors (CL-LBSi). International Journal of Case Studies in Business, IT, and Education (IJCSBE), 4(1), 207-222.

$* * * * * * *$ 